\title{
ARCHAE OLOGIA:
}

OR

\section{ISCELLANEOUS TRACTS}

RELATING TO

ANTIQUITY. 


\title{
ARCHÆOLOGIA :
}

\author{
- \\ M I S C E L L A N E O U S T R A C T S \\ RELATING TO \\ A N T I Q U I T Y, \\ PUBLISHED BY THE
}

SOCIETY OF ANTIQUARIES OF LONDON.

VOLUME XLIV.

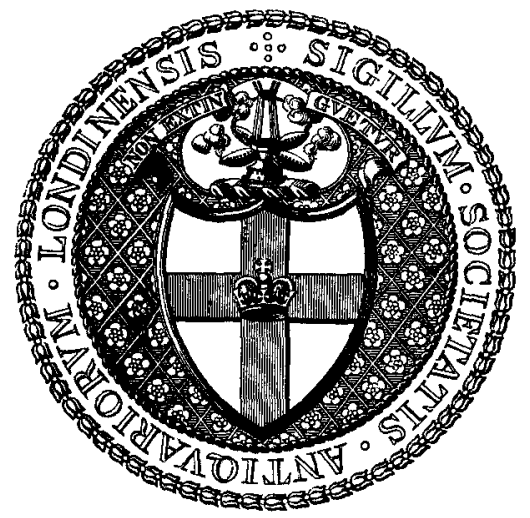

LONDON :

PRINTED BY NICHOLS AND SONS, 25, PARLIAMENT STREET.

SOLD AT THE SOCIETY'S APARTMENTS IN SOMERSET HOUSE.

M.DCCC.IIXXIII. 


\section{TABLE OF CONTENTS.}

PAGE

I.-On a probable allusion to the Christians in a Passage of the Sixth Satire of Juvenal. By The Earl Stanhope, D.C.L. F.R.S.

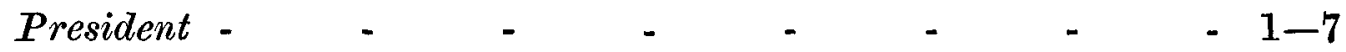

II.-Some Account of Ancient Oaken Coffins discovered on the lands adjoining Featherstone Castle, near Haltwhistle, Northumberland.

By Thomas William Snagge, Esq. M.A. - $\quad$ - $\quad$ - $\quad$ - 8-16

III.-Observations on the probable Sites of the Jewish Temple and Antonia and the Acra, with reference to the results of the recent Palestine Explorations. By Thomas Lewin, Esq. M.A. F.S.A. 17-62

IV.-Remarks on an Inscription on a Copper Dish found near Chertsey. Communicated by William Ralston Shedden Ralston, Esq. 63-64

V.-Observations on the hitherto unnoticed Expedition of the Emperor Augustus into Britain. By WILlTaM Henky Black, Esq. F.S.A. 65-80

VI.-Further Observations on the Expedition of the Emperor Augustus into Britain. By Wimliam Henry Black, Esq. F.S.A. - $\quad 81-92$

VII.-A Description of the Chapel of Saint Erasmus in Westminster Abbey. Communirated by J. T. Micklethwaite, Esq. - $\quad$ 93-99

VIII.-On an Example of Phalere and other Antiquities from Switzerland. Communicated by William Michael Wylie, Esq. F.S.A. Local Secretary for Hampshire - $\quad$ - $\quad$ - $\quad$ - $\quad$ - 100-112

IX.-An original Appointment of Sir John Fastolfe to be Keeper of the Bastille of St. Anthony, at Paris, in 1421. With Illustrative Remarks by JонN Godgr NichoLs, Esq.F.S.A. - - 113-123

X. - A Notice of some Remarkable Inscriptions on Leaves of Lead, preserved in the Manuscript Department of the British Museum. Communicated by WaLter dE Grax Birch, Esq. $123-136$

XI.-On Mediceval Representations of the Months and Seasons. Communicated by James FowLer, Esq. F.S.A. Local Secretary for Yorkshire - $\quad$ - $\quad$ - $\quad$ - $\quad$ - $\quad$ - $\quad$ -

XII. $-A$ Test of Certain Centurial Stones. Communicated by HenrY Charles Coote, Esq. F.S.A. - - - - - $\quad$ - 225-232 
XIII.-Further Facts in the History of the Early Discovery of Australia. By Richard Henry Major, Esq. F.S.A. $\quad 233-241$ Supplementary Facts in the History of the Discovery of Australia. By Richard Henry Major, Esq. F.S.A. 242-258 XIV.-On a Manuscript Book of Prayers in a Binding of Gold Enamelled, said to have been given by Queen Anne Boleyn to a lady of the Wyatt Family; together with a Transcript of its Contents. By the Honourable Robert Marsham 259-272 XV.-Notes on Discoveries in Ehenside Tarn, Cumberland. By R. D. Darbishtre, Esq. B.A. F.G.S. - - - 273-292 XVI.-On an Early French Deed, A.D. 1397, relating to the Knights of St. John of Jerusalem. Exhibited by EDward Peacock, Esq.; with Remarks by C. KNight Watson, Esq. M.A. F.S.A., Secretary - $\quad$ - $\quad$ - $\quad$ - $\quad$ - $293-298$

XVII.-The Milites Stationarii considered in relation to the Hundred and Tithing of England. By H. C. Coote, Esq. F.S.A. 299-320 XVIII.-On a Box of Carved Ivory of the Sixth Century. By Alexander NesbitT, Esq. F.S.A.; together with a Letter on the same subject by Padre Raffaele Garrucci, Hon. F.S.A. $321-330$

XIX.- Note on an Anglo-Saxon Knife, found in Kent, bearing an Inscription. By JoHn Evans, Esq. F.R.S. F.S.A. $331-334$ XX.-On the Origin of the AEra Dionysiana, or AEra Vulgaris, or AEra Christiana. By Dr. Gustav Oppert - $\quad$ - $335-352$ XXI.-On some Antique Gold and other Finger Rings found at Palestrina. $\quad B y$ C. Druny E. Fon'rndm, Esq. F.S.A. $\quad 353-362$ XXII.- Vortigern, not Hengest, the Invader of Kent. By HENRY Cinarles Coote, Esq. F.S.A. $\quad$ - $\quad$ - $\quad-\quad 363-372$ XXIII.-On the Crypt of the Chapter House, Westminster Abbey. By Henry Harrod, Esq. F.S.A. - - - 373-382 XXIV.-On Byzantine Churches, and the Modifications made in their Arrangements owing to the Necessities of the Greek Ritual. By Edwin Freshfield, Esq. M.A. F.S.A. - - $383-392$

XXV.-The Will, Inventories, and Funeral Expenses of James Montagu, Bishop of Winchester, anno 1618. From the original in the possession of the Baroness North. By Evelyn Philip Shirley, Esq. F.S.A. - - - $393-421$ 
XXVI.-Account of the Exploration of Tumuli at Trevelgue, or Trevalga, in the parish of St. Columb Minor, Cornwall; with Notes on a singular "Cliff Castle" on the same Estate. By Wrlliam Copeland Borlase, Esq. F.S.A. -

XXVII. - The Camps on the River Avon at Clifton, with Remarks on the Structure of Ancient Ramparts. By the Rev. H. M. ScARTH, $M . A$. $428-434$

XXVIII.-Remarks on some Pictures of Quintin Matsys and Holbein, in the Collection of the Earl of Radnor, at Longford Castle. By John Gough Nichols, Esq. F.S.A.

$43.5-458$

XXIX.-On Donnington Castle, Berhshire. By Henry Godwin, Esq. F.S.A. -

APPENDIX

Index - 


\section{LIST OF PLATES.}

PLATE

PAGE

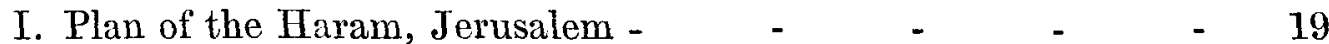

II. Westminster Abbey. Plan of the Chapel of Saint Erasmus - 94

III. Inscribed Plate of Lead in the British Museum - $\quad$ - 124

IV. Paving Tiles from Melton Mowbray Church - - 168

V. Glass from the Churches of Saint Mary, Shrewsbury, and All

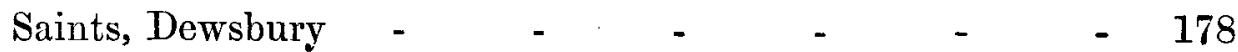

VI. Glass from the Mayor's Parlour at Leicester - $\quad$ - $\quad-179$

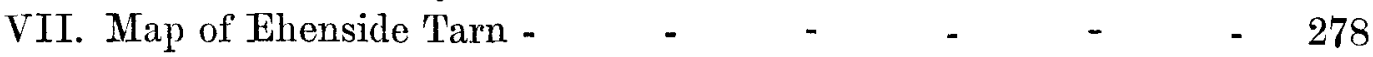

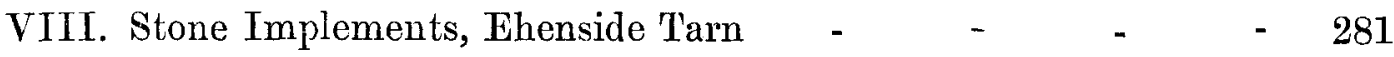

IX. Wooden Implements, Ehenside Tarn - $\quad-\quad y^{-} \quad-\quad 288$

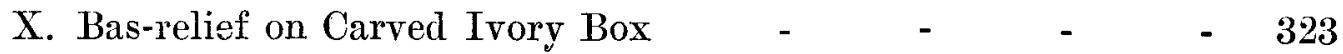

XI. Bas-relief on Carved Ivory Box - $\quad-\quad y_{1} \quad-\quad 324$

XII. Anglo-Saxon Knife found at Sittingbourne, Kent - $\quad-332$

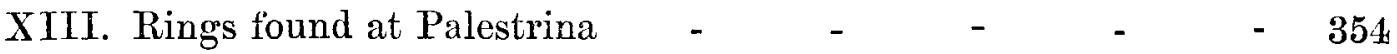

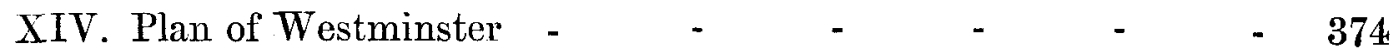

XV. Plans of East Ends of Byzantine Churches - $\quad$ - $\quad-\quad 384$

XVI. Ground Plan of a Greek Church $\quad-\quad$ - $\quad$ - $\quad$ - 385

XVII. Map of Camps on the River Avon - - - $\quad$ - $\quad-430$

XVIII. Anglo-Saxon Brooch found at Ragley Park, Warwickshire - 482

XIX. Cruciform Object found near the Cathedral Church of Saint

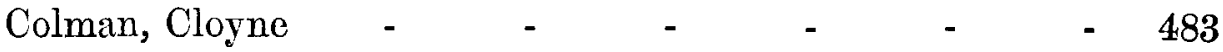




\section{E R R A T A.}

P. 316, note, line 7 from bottom:- for Zustanden read Zuständen Ibid. line 8 from bottom:-for Abtheilung ron read Abtheilung. Von P. 318, note 2, line 2, for curix read curia

P. 356, line 6, for periscelcis read periscelis

P. 369, last line, for perectly read perfectly 